図化機操作におけるオペレーターの作業負担と 疲労に関する実態調查 (II)

宇 佐 美 嘉 平*

\title{
Examination and Survey for Endurance and Fatigue of Operators in Operating the Plotting Instruments. (II)
}

by Y. Usami

Pacific Aero Survey Co.

\section{3. 疲労調查の成績}

\section{3-1. フリカッー值の変動}

フリッカー検査は大脳皮質の活動水準を示すものとし て汎用されているが，フリッカー值は夜間覚醒時作業の 影響がなくとも低下を来すという昼夜の生体リズムを示 すので，夜勤時等の検査では日勤午前時，普通作業前の 值に対する変動率をもって比較することが望ましい。勿 論测定值の個人差も大きいから，ここでは各人の日勤二 日の作業前值平均を基準として，それに対する各測定時 点の変動率 $(\%)$ を算出し，作業経過によるフリッカー 值の変動を検討した。

図 3-1 はオペレーター日勤, 夜勤, エジター日勤にわ けて二日間の毎検査時点での変動率の分布を示したもの である。両群とも日勤作業前は $\pm 2 \%$ の範囲にあるが， 作業時間の経過と共に負方向すなわちフリッカー值の低 下する方へ変動率は低下してゆき, 日勤終業時では -1 〜 - $8 \%$ の範囲に分布する。午前の作業終了時でも -4 〜ー5\%のものがみられる。作業に伴なう精神的緊張がフ リッカー值を上昇させる面が当然考えられるが，かかる 上昇は午前中や午後の作業前半では相対的にかなりのも のに認められるが，大半は作業経過と共に作業前值より 低い值を示すことが注目される。しかもこの低下傾问は エジターよりオペレーターで顕著となっている。

夜勤でも作業前值は午 3 後時で日勤時と余り変わらな い水準にあり同じ午後 3 時の日勤作業中の分布より高い 水準にある。しかし夜勤の作業時間と共に低下を示すも のがふえ，特に夕食後はすでに日勤終了時の水準にな り, 午後 11 時の終業時は -4 - $12 \%$ の分布となる。

* パシフイック航業株式会社

「写真測量」Vol. 6 No. 41967
勿論フリッカー值の変動は作業以外の要素でも異なるの で個人による作業内容や経過にそれぞれの差はあっても ここでは平坮的変動の比較をしたい。日別あるいは職 務別, 日夜勤別にみたフリッカー值変動率の平均経過は 図 3-2 の如くである。

日勤, 夜勤の第 1 日と第 2 日では作業前半の経過に若 干ちがいがみられる。すなわち日勤では第 1 日が低く, 夜勤では第 2 日が低い。しかし終業時では余り差異がな く, 日勤では平均 4 5\%, 夜勤では $8 \%$ 前後の低下と なる。

職種別の平均経過は第 1 日, 第 2 日の合計で日勤, 夜 勤とも作業経過とともにフリッカー值は順次低下の傾向 にあり，特に夜勤の場合著るしい。日勤では午後 3 時の 休憩までは -2〜ー3\%に停滞しているが，終業時には エジターで $-4 \%$, オペレター $5 \%$ に落ちている。助手 のそれは比較的低下が軽い。その反面午前 11 時頃や午 後 2 時頃の作業中のフリッカー值がオペレーターやエジ ターより低い傾向にある。夜勤時の経過はオペレターと 助手に余り差がないが, 夕食休憩以降, 特に午後 9 時以 降の低下が甚だしい。

各時点の変動率が $-3 \%$ 以下の もの夜勤では $-8 \%$ 以下のものの比率をも示したが, 平均変動率の低下と共 にこれらの比率も増加してくる。な掖勤時夕食休に入 浴した場合としない場合のフリッカー值変動率の平均経 過を示したが，全体としては余り差がない。唯入浴者で は夕食休蒩前後でのフリッカー值の低下が相対的に軽く なっているが，休憩前半の作業中のレベルが平均として 低く一概に入浴の効果とはいえない。それより入浴の有 無にかかわらず夜勤後半のフリッカー值の漸減的低下傾 向がみられることは入浴が夜勤時の作業に伴なうフリッ カー值変動に余り影響していないことを示している。 

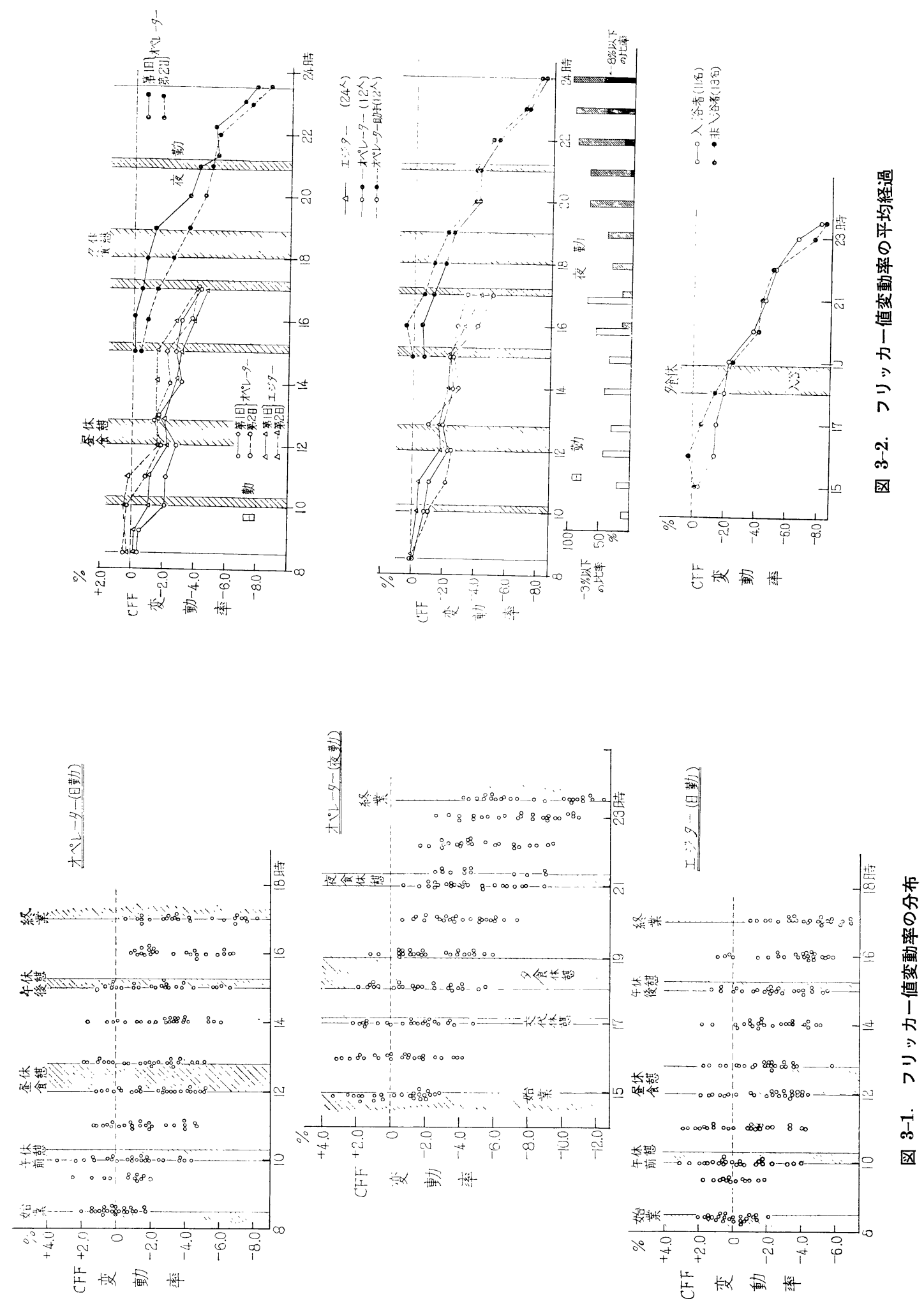
フリッカー値の変動から疲労を判定する基準としてあ げられているものにつぎの大島による判定基準と狩野の 夜勤時の判定基準がある。これらは実験的な値と各種の 調査事例の検討から，日勤あるいは夜勤での通常の勤務 負担と考えられる職種の変動分布から割り出されたもの である。

（）日勤時のフリッカー值変動率の望ましい限界(大島)

\begin{tabular}{|c|c|c|}
\hline 作 & 日間変動率 & $\begin{array}{l}\mid \text { 作業前值の| } \\
\text { 週間変動率 }\end{array}$ \\
\hline $\begin{array}{l}\text { A. エネルギ一消費の大きい肉 } \\
\text { 体作業 }\end{array}$ & $-10 \%$ & $-3 \%$ \\
\hline $\begin{array}{l}\text { B. 精神作業或いはエネルギー } \\
\text { 消費の大きくな作業 }\end{array}$ & $-5 \%$ & $-3 \%$ \\
\hline
\end{tabular}

○夜勤時のフリッカー値変動率判定基準 (狩野)

\begin{tabular}{|c|c|c|}
\hline 勤 & $\begin{array}{l}\text { 作業前後 } \\
\text { 変動率 }\end{array}$ & \begin{tabular}{|l|} 
日勤時午前中 \\
の測定值に対 \\
する作業後の \\
変動率 \\
\end{tabular} \\
\hline $\begin{array}{l}\text { A. } 15 \sim 16 \text { 時頃より翌朝ま } \\
\text { での勤務(連勤) (通常 } \\
\text { 仮眠 } 3 \sim 5 \text { 時間) }\end{array}$ & $\begin{array}{l}\text { 平均值で }-3 \\
\% \text { 以下でない } \\
\text { こと }\end{array}$ & $\mid \begin{array}{l}\text { 平均值が }-5 \\
\% \text { 以下でない } \\
\text { こと }\end{array}$ \\
\hline $\begin{array}{c}\text { B.20時以降より翌朝まで } \\
\text { の勤務(宿直) (通常仮 } \\
\text { 眠90分以内) }\end{array}$ & 上 & $\begin{array}{l}\text { 平均值が }-8 \\
\% \text { 以下でない } \\
\text { こと }\end{array}$ \\
\hline $\begin{array}{l}\text { C. } 13 \text { 時以降上り } 20 \sim 24 \text { 時 } \\
\text { までの勤務(霄勤) }\end{array}$ & $\begin{array}{l}\text { 平均值で }-4 \\
\% \text { 以下でない } \\
\text { こと }\end{array}$ & \\
\hline
\end{tabular}

このような基準に照らして今回の成続をみると, 日勤 時の終業時点での平均変動率は $-4 \sim-5 \%$ で望ましい 限界を超えていないが，ほぼそれに近い水準迄低下して いる。特に図化機オペレーターは $-5 \%$ である。但し 助手については $-3.5 \%$ で軽度であ る。しかし測定例には $-5 \%$ を超え るものが若干あるし，エジター，才ペ レターでは $1 / 3$ に達する。この点は 特に午後 3 時以降の作業に执いて顕著 であって，同じ日勤でもエジターより オペレーターでフリッカー值低下の大 きいものが多い。今回の夜勤は深夜の 勤務を含むものではなく，狩野の判定 基準の（C）霄勤に当るわけで，勤務 前值に比し $-8 \%$ に和よふ低下は明 らかにこの基準を凌駕している。 -4 $\%$ の線はほぼ午後 9 時までであって それ以降の低下は深夜勤時の明け方や 勤務後の基準に近いわけである。今回 の調查成績でのフリッカー值の低下は 日勤では特に著るしいとはいえないが 軽作業としてはかなりの低下を示して
おりまた夜勤のそれ浩鄞後半に打いて特に著るしい ということができよう。このようなフリッカー值の低下 は作業の負担と考えてよいのであるが，負担の内容につ いては一考を要しよう。

エジターあるいは図化機の作業は勿論肉体的にエネル ギー消費量の大きいものではなく，いわば神経感覚的な 努力を必要とするもので，そのような作業の遂行は精神 的緊張を必要とするから，ある作業時点まではかえって 精神的眮奮すなわち大脳皮質機能の克進を伴ない。フリ ッカー值の上昇がみられても良い筈である。ところがそ のような徵候は余りなく, 漸次的低下傾向が一般である ことは, 作業自体に打ける神経感覚的強度が大きいため にその長時間継続が終業時に执いてフリッカー值の低下 をもたらすというより，作業の遂行自体にはもはや熟練 して扣り逆に作業遂行がもつ単調感の維持がフリッカー 值の低下をもたらすように思われる。特に夜勤時は唯で さえ午後 9 時〜10時以降大脳機能の低下が避けられず, いわばねむけを催す時刻があって, 作業遂行の単調感と 環境の無刺激性も一種の作業負担といえるものであるう し, そのために生じる大脳機能の低下すなわち不活発化 の中で，所要の作業を遂行することは決して望ましいこ とではない。

\section{3-2. 近点距離の変動}

視賞は対象職種の作業遂行に不可欠のもので眼の疲労 をみる一方法として近点距離による遠近調節能を測った わけである。近点距離にはかなりの個人差があり $10 \mathrm{~cm}$ から $25 \mathrm{~cm}$ に拈よんでいる。各検査時点で 2 回測定し たので, 大きい方の值と小さい方の值について, オペレ ーター・エジターの毎日 12 名の平均経過を示したのが
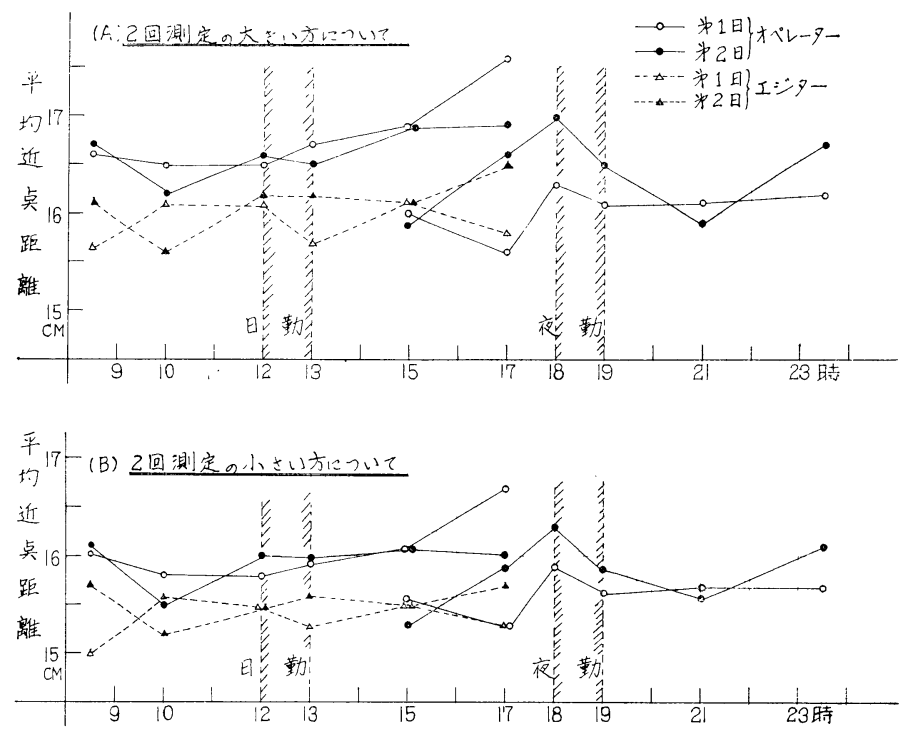

図 3-3. 近点距離の日別平均経過 


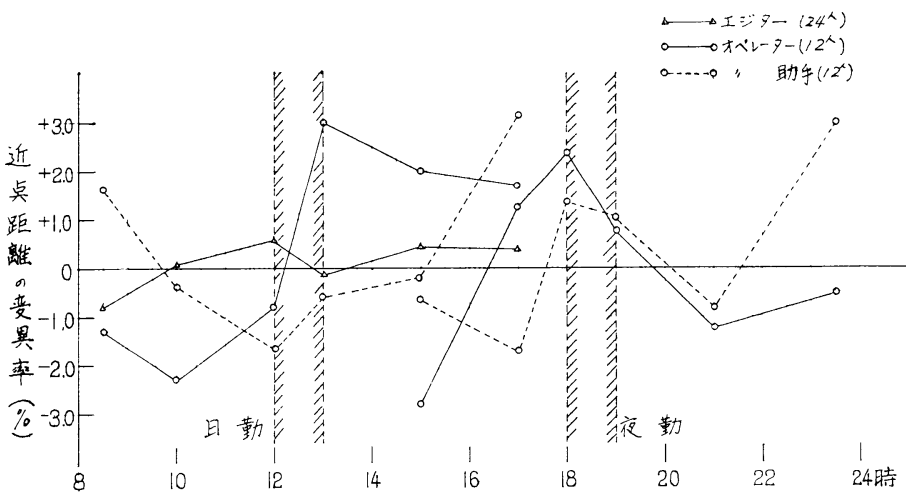

図 3-4 各人の平均近点距離に対する変異率の職種別平均経過

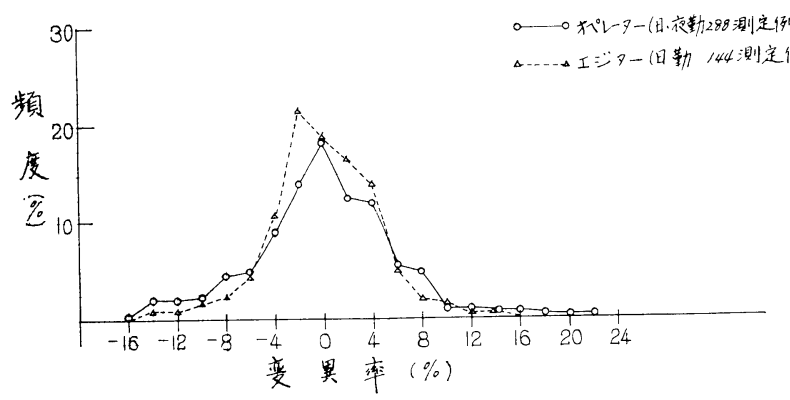

\begin{tabular}{|c|c|c|c|c|c|c|c|}
\hline \multicolumn{2}{|l|}{$\bar{\longleftarrow}$} & \multirow{2}{*}{$\frac{\text { 全例数 }}{144}$} & \multirow{2}{*}{$\frac{ \pm 3 \% \text { 内 }}{82(57 \%)}$} & \multicolumn{2}{|c|}{$\begin{array}{l}+3 \sim+7 \% \\
-3 \sim-7 \% \\
\end{array}$} & \multicolumn{2}{|c|}{$\begin{array}{l}+7 \% \text { : } 25 \\
-7 \% \text { 以下 }\end{array}$} \\
\hline エジター & 日勤 & & & 48 & $(33 \%)$ & 14 & $(10 \%)$ \\
\hline オペレーター & 日勤 & 144 & $67(46)$ & 38 & $(26)$ & 39 & (28) \\
\hline 及到助手 & 夜勤 & 144 & $64(44)$ & 51 & (36) & 29 & (20) \\
\hline ポレーター & 日夜勤 & 144 & $72 \quad(50)$ & 39 & (27) & 33 & (23) \\
\hline 手 & 日.夜勤 & 144 & $58 \quad(40)$ & 50 & (35) & 36 & (25) \\
\hline
\end{tabular}

図 3-5. 近点距離変異率の分布

図 3-3 である。2 回の測定值は過半数が $4 \mathrm{~mm}$ 以下し か違がわないが，中には $10 \mathrm{~mm}$ 以上異なるものが $20 \%$ もあって，大きい方の平均と小さい方の平均值の差は $4 \mathrm{~mm} \sim 8 \mathrm{~mm}$ となっている。これは一面測定の誤差と もいえるもので, 図 3-3 の平均経過は検査時点間で何 れも有意の差を示すものとはいえない。オペレーターよ りエジターが低いのは，対象個人のちがいであるが，同 じオペレーターの日勤時より夜勤時のレベルが低いのは 検査の馳れか，何か検査条件に起因するものか判然とし ない。

図 3-4 は各回 2 回の測定値の平均について，同一人 の 1 日間の測定值の平均レベルを基準に各時点の変異率 を求め，その職種別平均をみたものである。エジターで は時点間の変動が少ないのに比し, オペレーターで日勤 時午後は変異率は正方向に傾き，助手では勤務前後大き くなる。また夜勤でも変動が大きいのである。しかし $\pm 3 \%$ の変動内であってこの変異率の分布は図 3-5 に
見る如く $\pm 6 \%$ にも扮よぶものである ことからすると，必ずしも作業時間つ 経過で近点距離の短縮あるいは延長に 一定の傾向があるとはいえない。すな わち今回の測定成績では眼調節能の変 動を示す洼どの眼疲労を認めるには至 らなかったといえよう。但し図 3-4 や，図 3-5 でエジターより図化機作 業者で測られた近点距離に検査時点間 の変異が大きい傾向があるのであっ て，これは単なる測定上の個人差なの かあるいは作業と関連した眼機能上の 差異によるものかは何ともいえない。

\section{3-3. 下腿周の延長}

下腿周はほぼ $35 \mathrm{~cm} \sim 36 \mathrm{~cm}$ であっ て通常は作業活動によって若干增加し 安静横臥や睡眠によって旧に複するの であるが，作業姿勢や作業状況によっ てこの下腿周ののびが相違してくる。 椅座作業より立位作業が大きく，また 立位作業も歩行や移動の少ない立ちづ めの作業ではより大きく, 静水力学的 な静脈還流の障害によって大きく影響 されると考えられる。従来の測定例で は立業を主とする場合平均 $2 \%$ 前後 （約 $7 \mathrm{~mm}$ ）までの 增加が見られ，一 ケ所に止まって立位作業を行なう職種 では平均 $10 \mathrm{~mm}$ 内外の増加が見られ ている。下腿腫張の成因には静脈系の うつ血の法か，血管壁の弾性低下，組 織間液の増加，筋組織の膨化や充血など各種のものが考 えられるが明確なことはな打不明である。今回は主とし て椅座作業であるが，長時間の椅座も座面の圧迫で下肢 血行を阻害すること，また図化機オペレーターでは足の 動作から下腿筋の緊張も考元られるので，そのような姿 勢や動作の生体負担をみる方法としてとりあげたわけで ある。

困 3-6，3-7 は各人の作業前值を基準として各検査時 点の下腿周ののびの分布をみたものである。巻尺の測定 では若干誤差もさけ難いが作業時間経過と共に増加の方 向に分布してくることや，食事休㮩では明かに恢復が認 められることは，作業によって下腿の腫れがあることを 示している。作業前值は起床から会社までの生活活動の 内容にもよるわけで常にその人の最低值ではないから， 終業時点でも殆んど増加の示さないものもある。10 mm 以上の増加には若干測定誤差もあろうが，一応平均值で 日別の差をみると図 3-8 の如くになる。1 2 $\mathrm{mm}$ 前後 

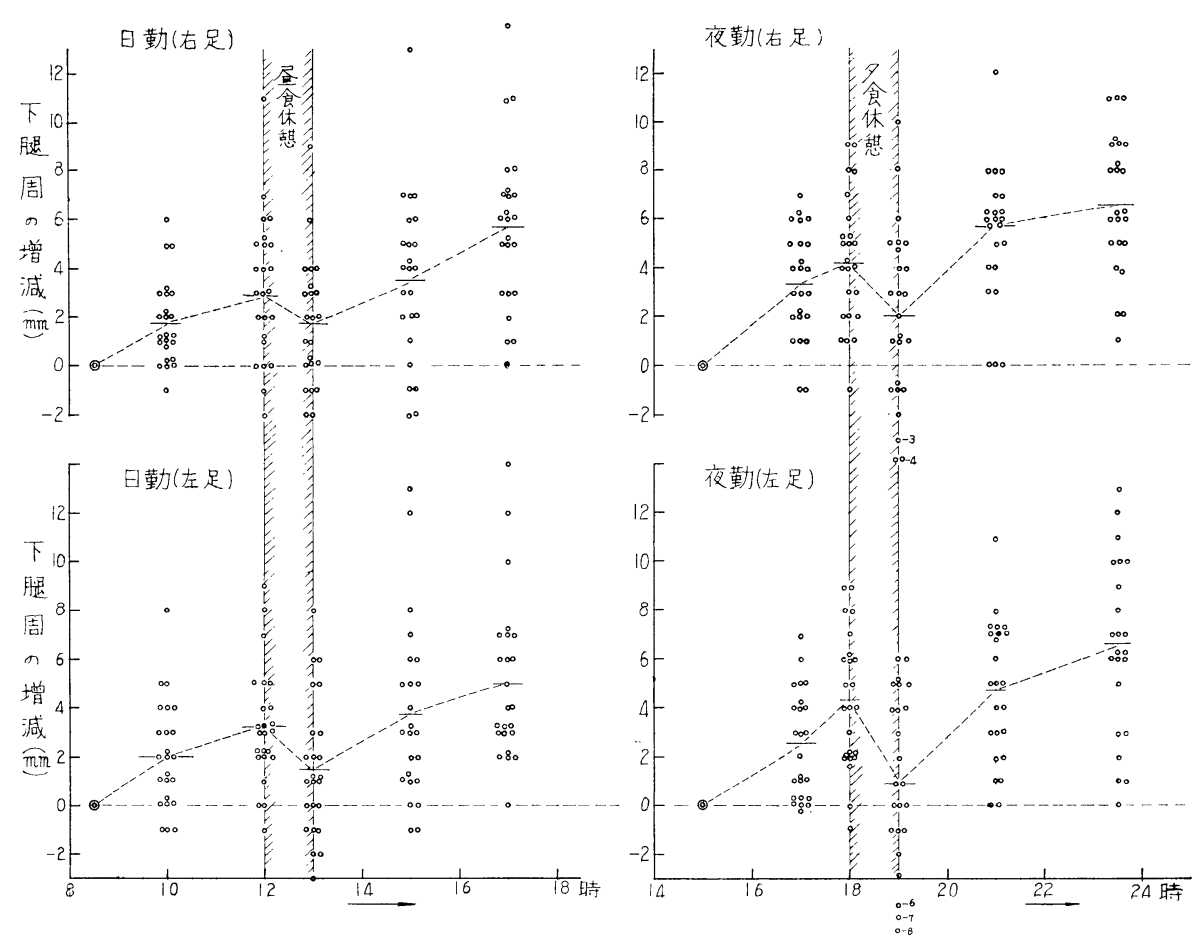

図 3-6. 下腿周の始業時に対する増減の時刻別分布（図化機作業員）

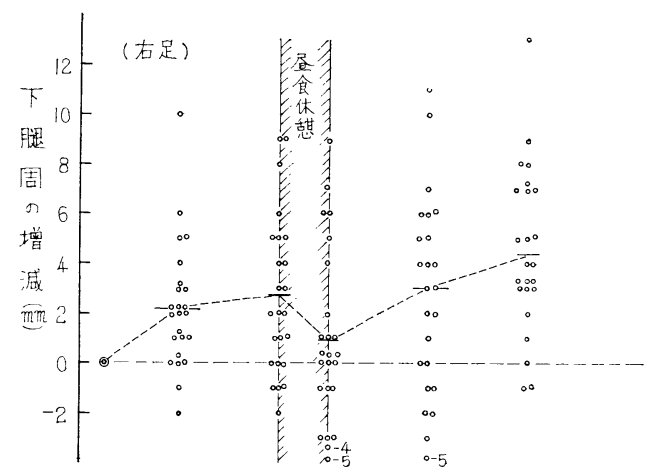

の差は有意とはいえないが，日勤午前作業でば $2 \sim 3 \mathrm{~mm}$ の増加, 午後の終業時 $3 \sim 6 \mathrm{~mm}$ の増加, 夜勤時は夕食 前で 3〜 $5 \mathrm{~mm}$, 終業時 5〜7 $\mathrm{mm}$ 増加となっている。 図 3-9 は職種別の平均であるが，職種間あるいは左右 足間に特に系統的な差異は認め難い。しかし日勤で 5 $\mathrm{mm}$, 夜勤で 6〜7 mm の延長は椅坐作業としては下腿 周増加の大きい部類に属するのであって，オペレーター は足の作業動作や, エジター, 助手では描画台や机にか がみこんで，時には立位の姿勢がとられること等に起因 していよう。

また一般に運動不足から血管系の緊張保持が不十分で うっ血を起し易いこともあるか子知れない。困 3-10 は 夜勤時の入浴者と非入浴者で下腿周の延長経過を比較し たもので，入浴によって著るしく回復していることが示 されている。しかし終業時点では余り差がなく,一時的 に血行をよくするが，血管の緊張度の回復がないために また急速に下腿の腫張が招来されるような傾向を示して いる。入浴の効果には風呂屋への歩行や, 外気にさらさ れる等の効果も含まれている。

\section{3-4. 血圧, 心拍数, 舌下温の変動}

血圧, 心拍数, 舌下温等は植物性機能として自律神経 系支配のもとにあって安静な状態では昼夜の時刻的変動 を示す。日勤に比し夜勤では勤務が 24 時近くに亘るこ とから, 身体のかかる機能にも差異を生じる。しかし一 面これらは身体活動や心的緊張, 外界温熱条件によって 

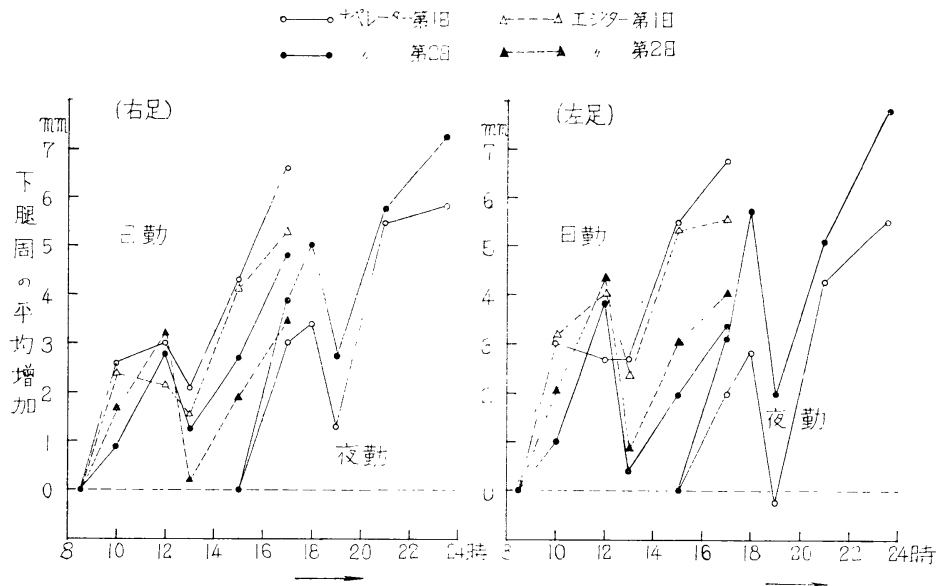

図 3-8. 下腿周平均変動の日別比較

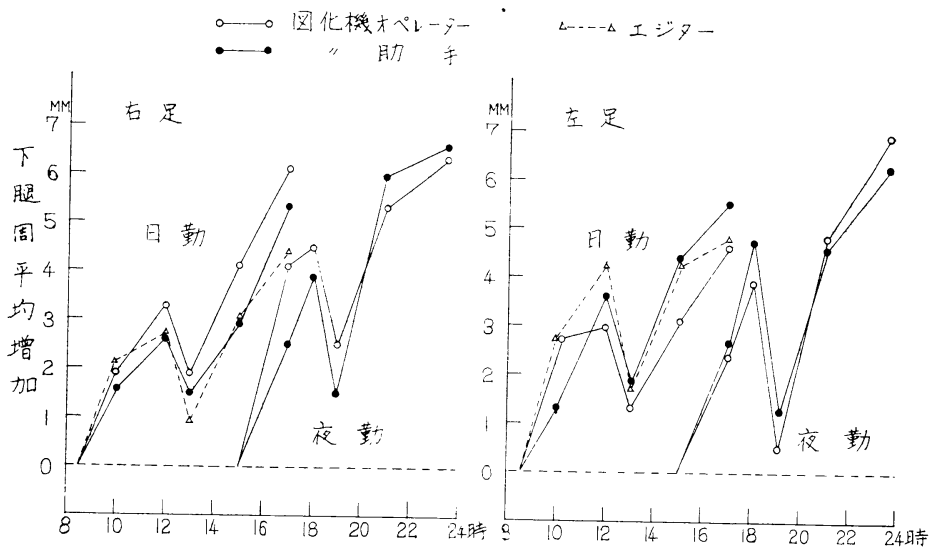

図 3-9. 下腿周平均変動の作業別比較

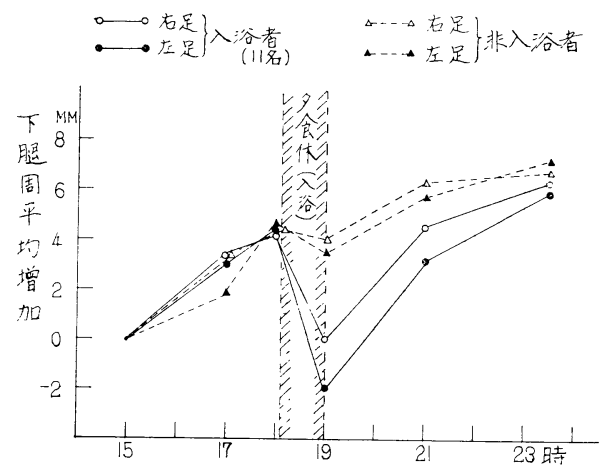

図 3-10. 下腿周変動におよぼす入浴の効果

も変動させられる。測定は勤務前, 昼夕食休㕰前, 勤務 後の 3 回行ない変動の様子を 2 日間の各検査時点の分布 からうかがった。図 3-11 は血圧で勿論個人差も大きい が，毎回同一対象群の测定であるから，大まかな変動推 移を見ることはできる。エジターでは最大血圧の変動は
ほとんどなく最小血圧は勤務後若干上昇し脈圧にも僅か に低下傾向にある。オペレーターの日勤は最大血圧の低 下と最小血压の上昇から脈圧の減少が平均 6 〜 $\mathrm{mmHg}$ におよんでいる。夜勤でも滦同じように最大血圧の低 下，最小血圧の上昇があって脈珐は減少を示すが，その 度合は日勤時とあまりかわらない。エジターに比しオペ レーターの方が身体活動が少ないためか，空気調節によ る恒温環境も影響していよう。しかし調查は 6 月上旬で 日中の空気調節による気温の内外差は余り差のないこと は身体活動の多少による面が大きいと思われる。

図 3-12 に示した舌下温は体温が日内変動として，午 後から夕刻に最高を示すことから，日勤では上昇が見ら れ，夜勤時も 18 時では高く,23 時の終業時では体温調 節上の熱放熱の增加や若干は気温の低下もあって舌下温 斗平坛的に低くなってくる。心拍数も日常生活では午前 より午後が高くなるのであるが，成績は勤務前より減少 の方向に推移している。この減少もエジターよりオペレ 一ターで大きく，また日勤と夜勤では余り差がない。 

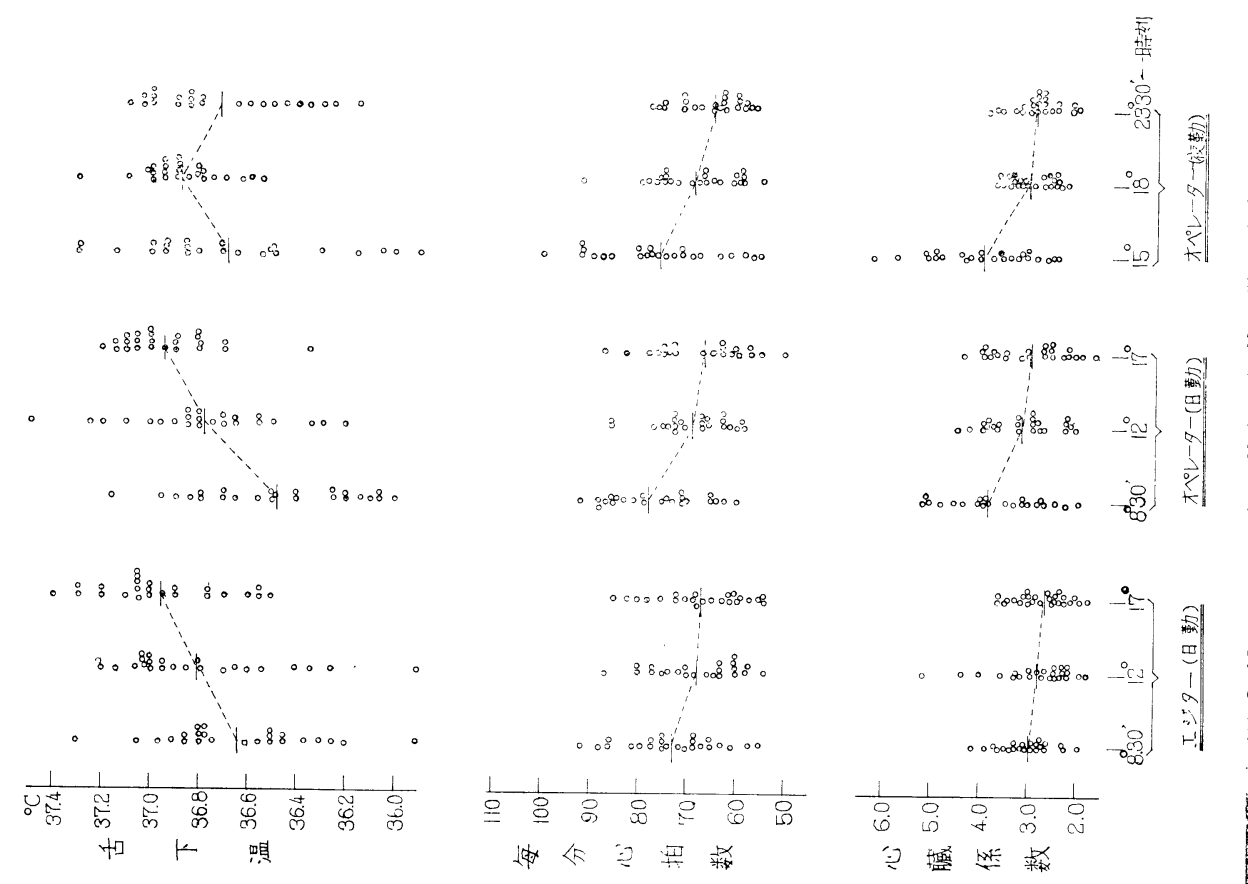

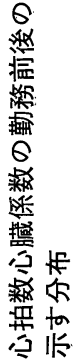

椋

吅督
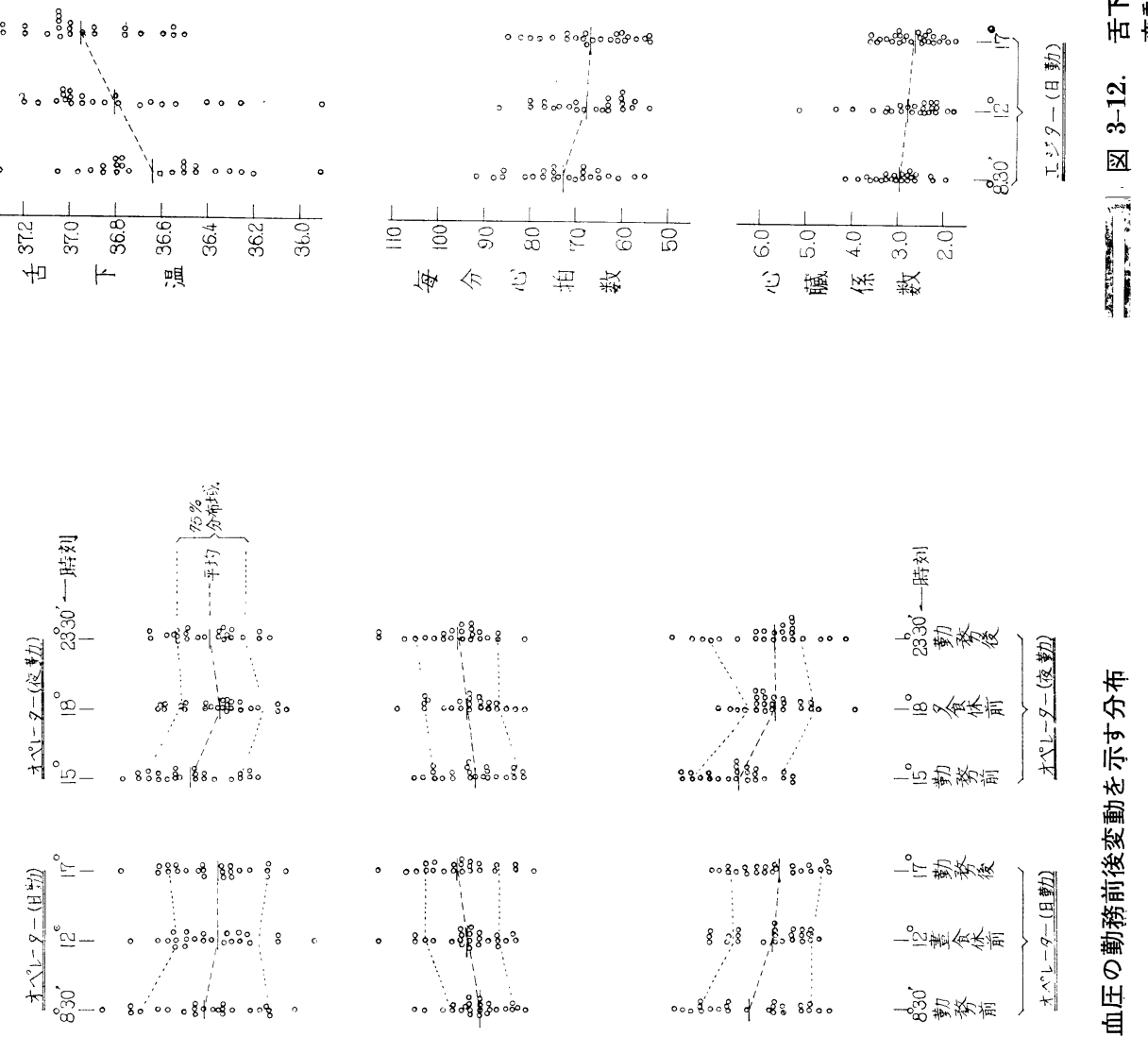

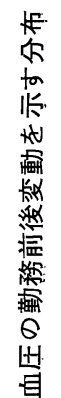
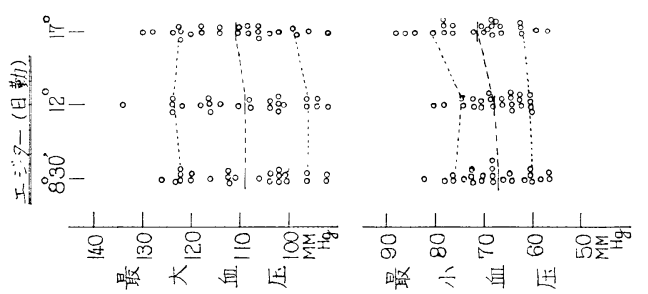

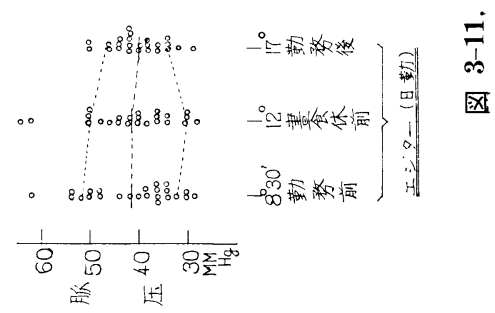


一般に自律神経機能の面で身体活動に適応した交感神 経系の優越状態は最大, 最小血圧の上昇（脈理も相対的 には増加), 体温の上昇, 心拍数の増加の方向として考 えられ, 逆に休養の体制としての副交感系の優越状態は 最大, 最小血圧の低下 (脈圧も減少), 体温の低下, 心 拍数減少の方向に変動するとされている。今回の変動方 向はこのいづれか一方に即しているものではないが，夜 勤の後半では若干副交感系優趣に傾くといった側面も否 定できない。しかしこのような自律神経系のバランスよ りも血圧, 心拍数にみられる変動は身体活動の不活発化
による心藏発化による心臓機能の沈静状態として考える べきものが少なくない。その点で脈圧と心拍数の積であ る心臓係数（心臓の送血量の個体別尺度とされている） を求めてみると,エジターでは勤務前に比し終業時 $10 \%$ 前後の低下が，オペレータでは日勤, 夜勤とも $25 \%$ 前後 の低下となっている。

\section{3-5. 睡液流量と喠液 $\mathrm{Na} / \mathrm{K}$ 比の変動}

唾液の分泌量や $\mathrm{Na} / \mathrm{K}$ 比の変動は消化器機能の面て の自律神経系の態度をみる簡便な方法としてとりあげら れている。一般に副交感系の優越した状態では唾液流量

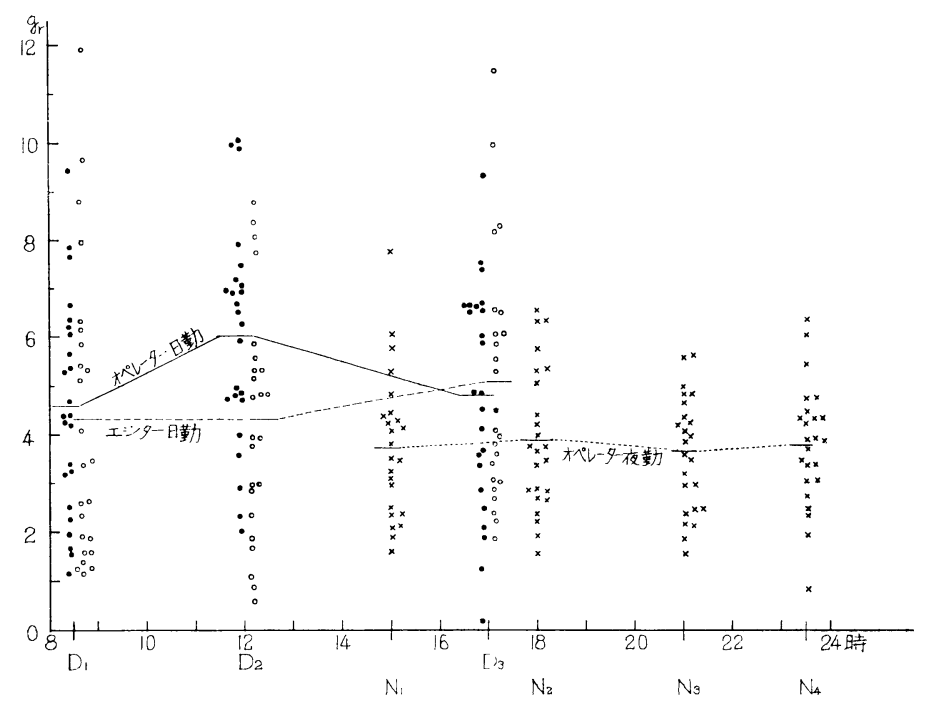

図 3-13. 唾液流量 (5 分間) の分布

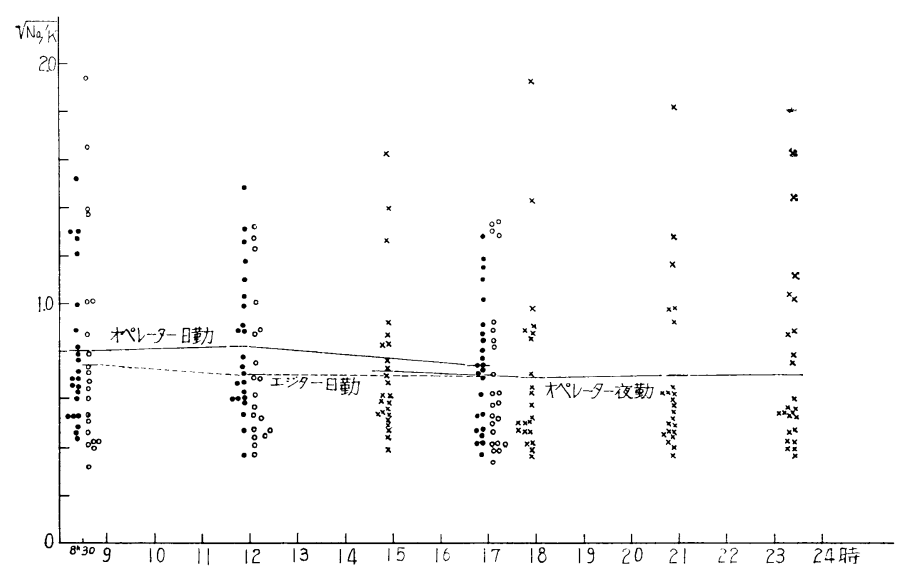

図 3-14. 唾液 $\sqrt{\mathrm{Na} / \mathrm{K}}$ 比逐時推移 


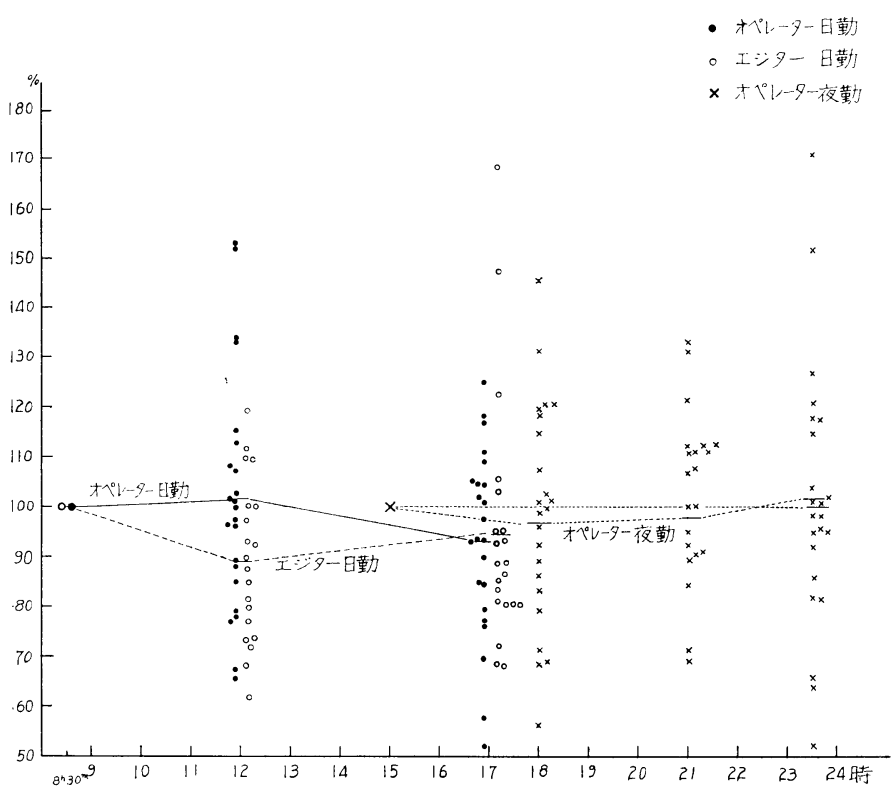

図 3-15. 唾液 $\mathrm{Na} / \mathrm{K}$ 比変動率の逐時推移

の増加, $\mathrm{Na} / \mathrm{K}$ 比の低下が起り，逆に交感系の優越では 流量の減少， $\mathrm{Na} / \mathrm{K}$ 比の上昇がみられるとされている。 したがって日内変動でも日中より夜間は唾液流量の増加 と $\mathrm{Na} / \mathrm{K}$ の低下が予想されるわけである。今回の成績 は図 3-13，3-14，3-15 に示す如く，唾液流量について は日勤より夜勤で一般に低值に分布がかたよって扣り， この点では交感系の優越となるのであるが，個人差の大 きいことから有意な差とはなっていない。もっとも測定 の誤差として 5 分間の唾液の口内貯溜中に飲み込まれた りすることもあったようで, 特に 1 グラム以下の值は正 しい測定とはいえないようである。一方 $\mathrm{Na} / \mathrm{K}$ 比につい のは，分布幅も大きいので平方根をとったが，若下夜勤 時低值に偏する傾向もあり副交感系の優越方向ともみら れ, 唾液流量とは逆の方向を想定させることとなる。もっ とも唾液流量がますと $\mathrm{K}$ 濃度が減じ $\mathrm{Na} / \mathrm{K}$ 比は高く なるという成績もあるから上記想定に固執しなければ矛 盾しているとはいえない。また消化機能の低下として唾 液分泌量の減少を考えることもできるわけであるが，今 回の成績では時刻的一定の変動傾向がみられない点から はこれらの日勤時と夜勤時の差を特に意義ずけることは むつかしいという他なく, 特別な所見はこれから見られ ないというのが正しいであろう。

\section{3-6. 自覚症状訴え率}

各項目別訴え率と (A), (B), (C) 項平均訴え率のエシ ター，オペレーター別各勤務前後の比率を示したのが表 3-1 である。勤務前に扮いてもこういった症状の訴えは 皆無ではなく，特にエジターは若千高い傾向にある。症 状としては勢務前では頭が扬もい，全身ないしどこかが
だるい，肩がこる，足がだるい，頭がぼんやりする，ね むい, 目がつかれる等で勤務後の訴え症状とも余りかわ らないものが多いのは一見疲労の回復が十分でないかの ごとく思わせる。しかしこれは一面勤務前の調査に执い て検査時点での症状を記入するより, 日々の作業による 疲学症状を記入したような記入上のミスもあるかも知れ ぬ。ここでは勤務後の症状を中心に考えて見たい。勤務 後の症状で訴え率 $30 \%$ 以上（○印），50\% 以上（○印） を拾い出すと, 次のようになる。

\begin{tabular}{|c|c|c|c|}
\hline & エジター & $\begin{array}{l}\text { オペレ } \\
\text { ター } \\
\text { (日勤) }\end{array}$ & $\begin{array}{l}\text { オペレ } \\
\text { ター } \\
\text { (夜勤) }\end{array}$ \\
\hline A 1. 頭が拈もい & & $\bigcirc$ & O \\
\hline 3. 全身がだるい & O & $\bigcirc$ & O \\
\hline 4.どこかがだるい & O & O & (2) \\
\hline 5. 肩がこる & & (0) & (0) \\
\hline 7. 足がだるい & (a) & (C) & (a) \\
\hline B 1. 頭がぼんやりする & $\bigcirc$ & 0 & \\
\hline 4.いらいらする & & 0 & \\
\hline 5. ねむくなる & & O & $\bigcirc$ \\
\hline C 1. 目がつかれる & (a) & (a) & (0) \\
\hline
\end{tabular}

このような症状はいづれの調査例でも比較的高率に出 やすいものである。頭重感, 身体特に足の㤐倦感, 肩こ り, 目のつかれ等は総体的には肉体的疲労症状であっ て，作業動作とも関連していることがわかる。これら症 状の訴え率は主観的なもの調査集団の構成や意識にも左 右され，一般的判定基準は容易に求められないが，この 症状調查表がつくられたときの全国的データーの平均值 と酒井，狩野による判定基準が報告されている。 
[作業疲労自覚症状訴え率の規淮 $]$

\begin{tabular}{|c|c|c|c|}
\hline & A. 身体的症状 & B. 精神的症状 & C. 神経感覚的症状 \\
\hline 全产業平均（6124 例，1955） & $19.1 \%$ & $12.2 \%$ & $9.8 \%$ \\
\hline \multirow[t]{2}{*}{$\begin{array}{l}\text { 酒井, 狩野に上る訴光率の望委しし規準の推 } \\
\text { 定值 }\end{array}$} & $19.6 \%$ & $11.6 \%$ & $13.1 \%$ \\
\hline & $14.3 \%$ & $12.4 \%$ & $13.4 \%$ \\
\hline
\end{tabular}

表 表 3-1 疲労自覚症状訴え率の項目的訴え頻度および勤務前後別平均訴え率 $(\%)$

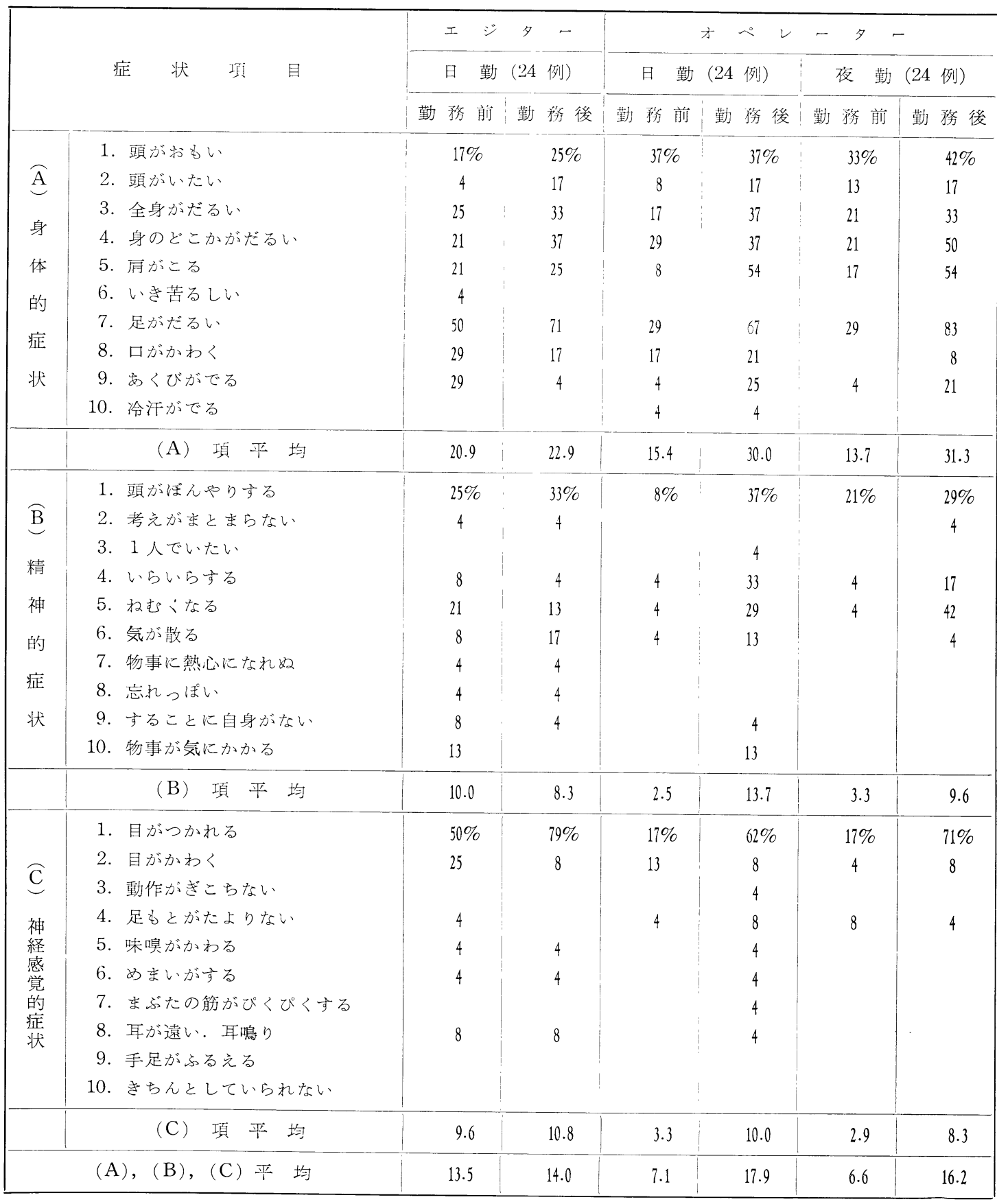


これにくらべると（A）項目では若干これを上廻り特 にオペレーターの訴え率が高いといえる。同じオペレー でも図化機オペレーターターと助手に区分して見ると表 3-2 のごとくで, 助手では余り高率ではないが，オペレ 一ターでは（A）項の平均訴え率は一段と高くなってい る。また助手では日勤より夜勤が若干訴え率は高率にな
るが，オペレーターのそれは叙差異がない。勿論これ から夜勤も日勤も大差ないという結論を出すことはでき ないが，雨者の疲労自覚に余り大きなちがいはなさそう に思われるのである。な拉参考までに他産業の交代勤務 職場の自覚症状訴え率を表 3-3 に示す。

表 3-2. 図化機オペレーターと助手の自覚症訴え率の比較 (12 例)

\begin{tabular}{|c|c|c|c|c|c|c|c|c|c|c|}
\hline \multirow{2}{*}{ 直 } & \multirow{2}{*}{ 別 } & \multirow{2}{*}{ 症状項目区分 } & \multicolumn{4}{|c|}{ 図化機オペレーター } & \multicolumn{4}{|c|}{ 困 化 機 助 手 } \\
\hline & & & 勤 & 務 前 & 勤 & 務 後 & 勤 & 務 前 & 勤 & 務 後 \\
\hline \multirow{4}{*}{ 日 } & \multirow{4}{*}{ 勤 } & $\mathrm{A}$ 項 平 均 & \multirow{2}{*}{\multicolumn{2}{|c|}{$\begin{array}{l}13.7 \% \\
2.5\end{array}$}} & \multicolumn{2}{|r|}{$39.2 \%$} & \multicolumn{2}{|r|}{$18.3 \%$} & \multicolumn{2}{|r|}{$20.8 \%$} \\
\hline & & $\mathrm{B}$ 項 平 均 & & & \multicolumn{2}{|r|}{16.7} & \multicolumn{2}{|r|}{2.5} & \multicolumn{2}{|r|}{10.8} \\
\hline & & $\mathrm{C}$ 項 平 均 & \multicolumn{2}{|r|}{3.3} & \multicolumn{2}{|r|}{13.7} & \multicolumn{2}{|r|}{3.3} & \multicolumn{2}{|r|}{3.3} \\
\hline & & $\mathrm{A} \cdot \mathrm{B} \cdot \mathrm{C}$ 平均 & \multicolumn{2}{|r|}{6.3} & \multicolumn{2}{|r|}{21.6} & \multicolumn{2}{|r|}{8.0} & \multicolumn{2}{|r|}{11.6} \\
\hline \multirow{4}{*}{ 夜 } & \multirow{4}{*}{ 勤 } & $\mathrm{A}$ 項 平 均 & \multicolumn{2}{|r|}{10.8} & \multicolumn{2}{|r|}{40.0} & \multicolumn{2}{|r|}{16.6} & \multicolumn{2}{|r|}{27.5} \\
\hline & & $\mathrm{B}$ 項 平 均 & \multicolumn{2}{|c|}{0.8} & \multicolumn{2}{|r|}{10.8} & \multicolumn{2}{|r|}{5.8} & \multicolumn{2}{|r|}{8.0} \\
\hline & & $\mathrm{C}$ 項 平 均 & \multicolumn{2}{|r|}{1.7} & \multicolumn{2}{|r|}{1.7} & \multicolumn{2}{|r|}{6.0} & \multicolumn{2}{|r|}{5.0} \\
\hline & & $\mathrm{A} \cdot \mathrm{B} \cdot \mathrm{C}$ 平均 & \multicolumn{2}{|r|}{4.4} & \multicolumn{2}{|r|}{20.5} & & 9.5 & & 13.4 \\
\hline
\end{tabular}

表 3-3. 交代勤務職場の作業後自覚症状訴え率（\%）

\begin{tabular}{|c|c|c|c|c|c|}
\hline 交 代 様 式（業職） & & & (A) 身体的症状 & (B) 精神的症状 & (C) 神経感覚的症状 \\
\hline \multirow{3}{*}{$\begin{array}{c}3 \text { 組 } 3 \text { 交代 (アルミナ製造) } \\
\text { (8月) }\end{array}$} & 日 & 勤 & $11.0 \%$ & $2.6 \%$ & $2.8 \%$ \\
\hline & 肖 & 勤 & 13.4 & 5.1 & 3.4 \\
\hline & 夜 & 勤 & 22.8 & 11.4 & 11.0 \\
\hline \multirow{3}{*}{$\begin{array}{c}4 \text { 組 } 3 \text { 交代 (火力発電所) } \\
\text { (6月) }\end{array}$} & 日 & 勤 & 22.3 & 15.6 & 13.1 \\
\hline & 宵 & 勤 & 22.2 & 13.2 & 10.8 \\
\hline & 夜 & 勤 & 30.2 & 23.6 & 20.9 \\
\hline \multirow{3}{*}{$\begin{array}{c}3 \text { 組 } 3 \text { 交代 (製糖工場) } \\
(8 \text { 月) }\end{array}$} & 日 & 勤 & 33.0 & 20.7 & 16.4 \\
\hline & 宵 & 勤 & 33.0 & 21.7 & 16.2 \\
\hline & 夜 & 勤 & 41.0 & 32.4 & 24.4 \\
\hline \multirow{3}{*}{$\begin{array}{c}4 \text { 組 } 3 \text { 交代 (航空機整備) } \\
(7 \text { 月 })\end{array}$} & 日 & 勤 & 40.0 & 26.7 & 24.0 \\
\hline & 宵 & 勤 & 26.1 & 21.0 & 12.6 \\
\hline & 夜 & 勤 & 33.3 & 32.2 & 28.5 \\
\hline
\end{tabular}

